\title{
Infectious tenosynovitis of the long head of the biceps caused by methicillin-resistant Staphylococcus aureus in a patient with diabetes and small cell lung cancer
}

\author{
Kohei Horiuchi, ${ }^{\oplus}$ Takanori Asakura, ${ }^{1,2}$ Yuki Bessho, ${ }^{3}$ Fumitake Saito ${ }^{1}$
}

'Department of Pulmonary Medicine, Eiju General Hospital, Taito-ku, Tokyo, Japan ${ }^{2}$ Division of Pulmonary Medicine, Department of Medicine, Keio University School of Medicine, Shinjuku-ku, Tokyo, Japan

${ }^{3}$ Department of Orthopaedic Surgery, Eiju General Hospital, Taito-ku, Tokyo, Japan

\section{Correspondence to} Dr Kohei Horiuchi, kohei.horiuchi17@gmail.com

Accepted 23 February 2019

\section{DESCRIPTION}

A 51-year-old man presented with pain in the left upper arm and could not raise it above his shoulder. Six months before, he was diagnosed with small cell lung cancer with liver metastases and had undergone five platinum-based chemotherapy courses. He had been receiving intensive insulin therapy for diabetes. Clinical examination revealed high fever, tachycardia and a solid smooth mass with tenderness in his upper arm. Left arm MRI showed a long head of the biceps tendon surrounded by T2 high-signal intensity fluid containing an intertubercular tendon sheath that indicated tenosynovitis (figure 1). Needle aspiration of the cyst revealed purulence. Gram staining revealed gram-positive cocci in clusters suggestive of Staphylococcus aureus which was later confirmed to be methicillin-resistant Staphylococcus aureus (MRSA). Blood

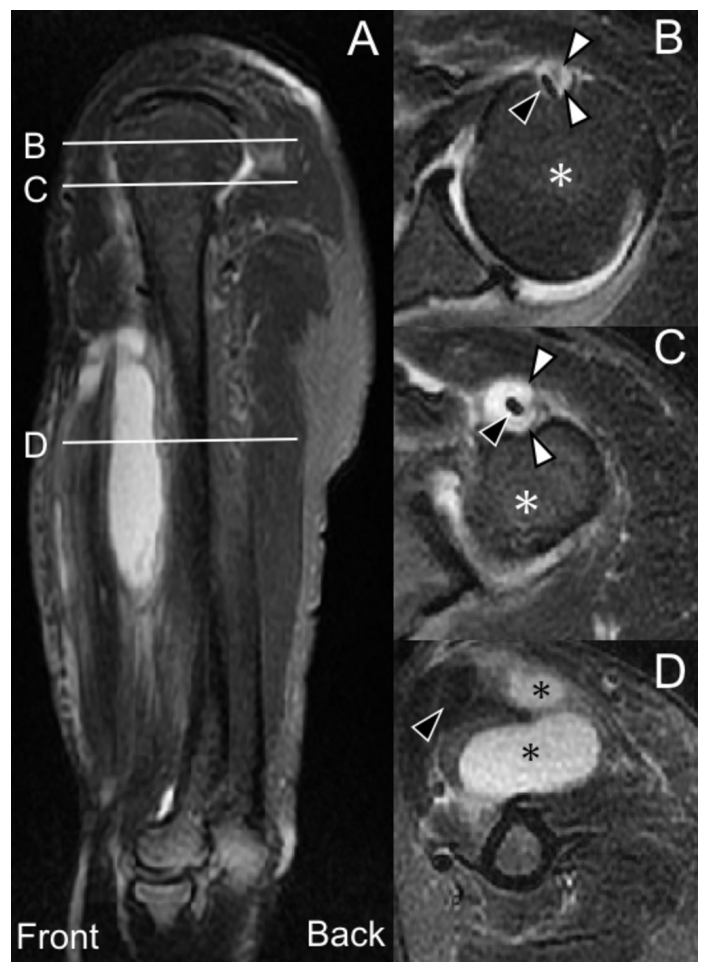

Figure 1 T2-weighted MRI of the left arm ( $A$, sagittal slice; $B$, axial slice) showing the tendon of the long head of the biceps (black arrowhead) surrounded by $\mathrm{T} 2$ highsignal intensity fluid containing an intertubercular tendon sheath (white arrowhead) (B and C, white star showing the humerus) and a multilobular cyst (black star) (D). cultures did not detect any organism. Based on the gram staining findings, treatment was initiated with vancomycin and drainage, and the patient became afebrile in several days. Drainage decreased the mass, enabling the patient to raise his left arm. After 2 weeks, vancomycin was changed to linezolid for renal dysfunction. Four weeks after the initial treatment, linezolid was switched to sulfamethoxazole/trimethoprim and rifampicin for elevated potassium level due to a suspected drug complication. The patient was discharged and showed complete recovery after 10 total weeks of antimicrobial therapy and is currently being followed up.

Common causes of tenosynovitis are overuse, infection, and occasionally connective tissue diseases. Infectious tenosynovitis commonly occurs in hand flexors, with $S$. aureus being the major organism. ${ }^{1}$ An infectious aetiology for tenosynovitis of the long head of the biceps has never been reported. In our case, an immunocompromised state with malignancy and diabetes may have contributed to the infection. Patients with diabetes, especially those using insulin, have a high risk for colonising MRSA. In one prospective study involving 304 patients with diabetes, MRSA colonisation was confirmed in $9.9 \%$ and that with insulin use was $16.9 \%$, insulin injection being an independent risk factor. ${ }^{2}$ Because our patient was right handed and preferred the left upper arm for the injection, cutaneous insulin injection may have been causal. Although the blood stream may have been the infectious pathway, blood culture results were negative. Clinicians who suspect musculoskeletal infections, even in rare infection sites, in patients with diabetes using insulin should consider initial MRSA coverage.

\section{Learning points}

- Patients with diabetes using insulin may have musculoskeletal infections in rare locations.

- Initial MRSA coverage should be considered when clinicians encounter musculoskeletal infections in patients with diabetes using insulin, even in rare infection sites.

Contributors $\mathrm{KH}$ and $\mathrm{YB}$ provided patient care. $\mathrm{KH}$ and TA wrote the initial draft of the manuscript. FS supervised the study and suggested critical revisions regarding important intellectual content. All authors approved the final version as submitted to the journal. 


\section{Images in...}

Funding The authors have not declared a specific grant for this research from any funding agency in the public, commercial or not-for-profit sectors.

Competing interests None declared.

Patient consent for publication Obtained.

Provenance and peer review Not commissioned; externally peer reviewed.

\section{REFERENCES}

1 Small LN, Ross JJ. Suppurative tenosynovitis and septic bursitis. Infect Dis Clin North Am 2005:19:991-1005

2 Kutlu SS, Cevahir N, Akalin S, et al. Prevalence and risk factors for methicillin-resistant Staphylococcus aureus colonization in a diabetic outpatient population: a prospective cohort study. Am J Infect Control 2012;40:365-8.

Copyright 2019 BMJ Publishing Group. All rights reserved. For permission to reuse any of this content visit

https://www.bmj.com/company/products-services/rights-and-licensing/permissions/

BMJ Case Report Fellows may re-use this article for personal use and teaching without any further permission.

Become a Fellow of BMJ Case Reports today and you can:

- Submit as many cases as you like

Enjoy fast sympathetic peer review and rapid publication of accepted articles

- Access all the published articles

Re-use any of the published material for personal use and teaching without further permission

For information on Institutional Fellowships contact consortiasales@bmjgroup.com

Visit casereports.bmj.com for more articles like this and to become a Fellow 